\title{
Kedudukan Hukum Peraturan Desa dalam Sistem Peraturan Perundang-Undangan
}

\author{
Legal Status of the Country Regulatory in the Regulatory System
}

\author{
Agustin \\ Universitas Halu Oleo \\ E-mail: Agustinlala86@gmail.com \\ Muh. Sabaruddin Sinapoy \\ Pascasarjana Universitas Halu Oleo \\ E-mail: sabaruddinsinapoy@yahoo.com \\ Kamaruddin Jafar \\ Pascasarjana Universitas Halu Oleo \\ E-mail: Kamaruddinjafar88@gmail.com
}

\begin{abstract}
Village Regulation is a statutory regulation stipulated by the Village Head after being discussed and agreed upon with the Village Consultative Body. After Law Number 12 Year 2011 concerning the Establishment of Legislation Regulations, it removes village regulations in the type and hierarchy of laws and regulations.

Village regulations in the form of draft Village Regulations, get evaluations from the Regent/Mayor before they are determined to be Village Regulations. Regarding the establishment of Village Regulations, guidance and supervision is carried out by the Regency/City Government as intended, namely evaluating and supervising Village Regulations. Supervision in this matter includes the cancellation of village regulations.
\end{abstract}

Keyword: Legal Position; Village Regulation; Legislation

Abstrak: Peraturan Desa adalah peraturan perundang-undangan yang ditetapkan oleh Kepala Desa setelah dibahas dan disepakati bersama Badan Permusyawaratan Desa. Setelah Undang-Undang Nomor 12 Tahun 2011 Tentang Pembentukan Peraturan Perundang-Undangan berlaku, menghapus peraturan desa dalam jenis dan hierarki peraturan perundang-undangan.

Peraturan Desa yang berbentuk rancangan Peraturan Desa, mendapatkan evaluasi dari Bupati/Walikota sebelum ditetapkan menjadi Peraturan Desa. Terkait dengan pembentukan Peraturan Desa, pembinaan dan pengawasan dilakukan oleh Pemerintah Kabupaten/Kota sebagaimana dimaksud yakni melakukan evaluasi dan pengawasan Peraturan Desa. Pengawasan dalam hal ini adalah termasuk pembatalan peraturan desa.

Kata kunci: Kedudukan Hukum; Peraturan Desa; Peraturan Perundang-Undangan 


\section{PENDAHULUAN}

Keberhasilan pelaksanaan pembangunan masyarakat desa (community development) sangat bergantung kepada peranan pemerintahan desa dan masyarakatnya. Keduanya harus mampu menciptakan sinergi untuk mencapai hasil pembangunan yang optimal.

Oleh karena itu, konsep sebuah desa merupakan wilayah yang memiliki basis otonomi asli. ${ }^{1}$ Menurut Pasal 1 angka 12 Undang-Undang (UU) Nomor 32 Tahun 2004 tentang Pemerintahan Daerah, Desa adalah kesatuan masyarakat hukum yang memiliki batas-batas wilayah yurisdiksi, dan berwenang untuk mengatur dan mengurus kepentingan masyarakat setempat berdasarkan asal-usul dan adat istiadat setempat yang diakui dan/atau dibentuk dalam sistem pemerintahan nasional dan berada di daerah kabupaten atau kota.

Maka, Desa sebagai suatu organisasi (publik) atau lembaga pemerintahan maupun sebagai entitas kesatuan masyarakat hukum yang memiliki batas-batas wilayah tertentu, memiliki kedudukan dan fungsi yang sangat penting dan strategis dalam rangka memperkuat struktur pemerintahan Negara Kesatuan Republik Indonesia (NKRI). Akan tetapi, adanya pengaturan mengenai Desa melalui berbagai peraturan perundang-undang yang ada, ternyata belum dapat mewadahi segala kepentingan dan kebutuhan masyarakat desa. Hal ini menjadi dasar pertimbangan yuridis lahirnya Undang-Undang Nomor 6 Tahun 2014 tentang Desa yang ditetapkan pada tanggal 15 Januari $2014 .^{2}$

Seiring penerapan Undang-Undang Nomor 6 Tahun 2014 Tentang Desa, maka peran pemerintahan desa menjadi sangat penting artinya untuk meningkatkan peran serta masyarakat untuk meningkatkan kesejahteraannya. Berdasarkan ketentuan dalam Pasal 20 Undang-Undang Nomor 6 Tahun 2014 bahwa pelaksanaan kewenangan berdasarkan hak asal usul dan kewenangan lokal berskala Desa yang diatur dan diurus oleh Desa. Penjelasan Undang-Undang Desa pun memberikan uraian terkait pentingnya Peraturan Desa tentang kewenangan berdasarkan hak asal usul dan kewenangan lokal berskala desa. Peraturan Desa adalah peraturan perundang-undangan yang ditetapkan oleh Kepala Desa setelah dibahas dan disepakati bersama Badan Permusyawaratan Desa. Peraturan desa merupakan penjabaran lebih lanjut dari peraturan perundang-undangan yang lebih tinggi

1 Rahardjo, Pengantar Sosiologi Pedesaan dan Pertanian, Yogyakarta: Gadjah Mada University Press, 1999, hlm. 13.

2 Penjelasan Umum Undang-Undang Nomor 6 Tahun 2014 tentang Desa. 
dengan memperhatikan kondisi sosial dan budaya masyarakat desa setempat, dalam rangka penyelenggaraan otonomi desa dengan memperhatikan ciri dan budaya lokal.

Namun, dalam Undang-Undang Nomor 12 Tahun 2011, Peraturan Desa tidak disebutkan secara tegas, terutama pada Pasal 7, Peraturan Desa tidak termasuk dalam hierarki peraturan perundang-undangan. Selanjutnya dalam ketentuan Pasal 8 ayat (2) yang menyatakan bahwa Peraturan Perundang-undangan sebagaimana dimaksud pada ayat (1) diakui keberadaannya dan mempunyai kekuatan hukum mengikat sepanjang diperintahkan oleh Peraturan Perundang-undangan yang lebih tinggi atau dibentuk berdasarkan kewenangan. Bila kita lihat dalam Pasal 8 ayat (1), jenis Peraturan Perundang-undangan selain sebagaimana dimaksud dalam Pasal 7 ayat (1) mencakup peraturan yang ditetapkan oleh Majelis Permusyawaratan Rakyat, Dewan Perwakilan Rakyat, Dewan Perwakilan Daerah, Dewan Perwakilan Rakyat Daerah Provinsi, Gubernur, Dewan Perwakilan Rakyat Daerah Kabupaten/Kota, Bupati/Walikota, Kepala Desa atau yang setingkat. Bila dilihat, maka Peraturan yang dimaksud dalam ketentuan tersebut adalah Peraturan Kepala Desa bukan Peraturan Desa.

Merujuk pada hierarki peraturan perundang-undangan yang tidak menempatkan Peraturan Desa di urutannya, maka hal ini akan menimbulkan kesulitan dan permasalahan dalam menentukan kedudukan hierarki Peraturan Desa dalam hierarki peraturan perundang-undangan di Indonesia. Oleh karena itu, penulis tertarik untuk menulis tentang Kedudukan Hukum Peraturan Desa Dalam Sistem Peraturan Perundang-Undangan.

Tulisan ini hendak menjawab dua permasalahan, yakni pertama, Bagaimana Kedudukan Hukum Peraturan Desa Dalam Sistem Peraturan Perundang-undangan? Kedua, Sistem Pengujian Peraturan Desa Dalam Sistem Hukum Perundang-undangan?

\section{METODE PENELITIAN}

Jenis penelitian/pendekatan yang digunakan oleh penulis adalah penelitian hukum normative empiris. Penelitian hukum normative menurut Peter Mahmud Marzuki ${ }^{3}$ yaitu penelitian hukum yang dilakukan dengan pendekatan undang-undang (statute approach), pendekatan kasus (case approach), pendekatan historis (historical approach), pendekatan komparatif (comparative approach), dan pendekatan konseptual (conceptual approach).

3 Peter Mahmud Marzuki, Penelitian Hukum, Jakarta: Kencana Prenada Media Group, 2005, hlm. 93. 
Sedangkan normative empiris, ${ }^{4}$ yakni penelitian yuridis dilakukan dengan cara meneliti bahan pustaka yang merupakan data sekunder dan juga disebut penelitian kepustakaan. Penelitian hukum empiris dilakukan dengan cara meneliti di lapangan yang merupakan data primer.

\section{ANALISIS DAN PEMBAHASAN}

\section{Kedudukan Hukum Peraturan Desa Dalam Sistem Peraturan Perundang-undangan}

\section{Sistem Peraturan Perundang-undangan}

Sistem perundang-undangan suatu negara tidak akan lepas dari sistem hukum yang berlaku di suatu negara, karena "Peraturan Perundang-undangan" sebagai hukum tertulis merupakan esensi atau bagian yang sangat penting dari "sistem hukum" dari negara hukum (modern) yang demokratis. Dalam aspek kesejarahan, sistem hukum tidak lepas dari konsep negara, konsep negara hukum, dan sistem pemerintahan, yang berkembang dan dipraktikkan sejak zaman Yunani Purba sampai sekarang (abad 21). Sistem peraturan perundang-undangan erat kaitannya dengan sistem hukum, karena peraturan perundangundangan sebagai hukum tertulis merupakan bagian/unsur dari sistem hukum yang secara universal terdiri atas structure, substance dan culture..$^{5}$ Artinya, suatu sistem adalah seperangkat komponen, elemen, unsur atau sub sistem dengan segala atributnya yang satu sama lain saling berkaitan, pengaruh mempengaruhi dan saling tergantung, sehingga keseluruhannya merupakan suatu kesatuan yang terintegrasi serta mempunyai peranan atau tujuan tertentu. Dari pengertian di atas, maka sistem peraturan Perundang-undangan adalah satu kesatuan dari seluruh peraturan perundang-undangan yang satu sama lain saling berhubungan dan merupakan sub-sub sistem yang terintegrasi dalam satu kesatuan yang bulat dan tidak bertentangan antara satu dengan yang lainnya.

Oleh karena itu, keberadaan Pembentukan Peraturan Perundang-undangan dimaksudkan untuk membentuk suatu ketentuan yang baku dan memberikan pedoman pasti mengenai tata cara Pembentukan Peraturan Perundang-undangan. Menurut UndangUndang Nomor 12 Tahun 2011 tentang Pembentukan Peraturan Perundang-undangan, dinyatakan bahwa Peraturan Perundang-undangan adalah peraturan tertulis yang memuat norma hukum yang mengikat secara umum dan dibentuk atau ditetapkan oleh

4 Ronny Hanitijo Soemitro, Metode Penelitian Hukum dan Jurimetri, Jakarta: Ghalia Indonesia, 1990, hlm. 36.

5 Machmud Aziz, Pengujian Peraturan Perundang-Undangan dalam Sistem Peraturan Perundang-Undangan Indonesia, Jurnal Konstitusi, Volume 7, Nomor 5, Oktober 2010, hlm. 118. 
lembaga negara atau pejabat yang berwenang melalui prosedur yang ditetapkan dalam Peraturan Perundang-undangan.

\section{Peraturan Desa}

Peraturan yang melandasi penyelenggaraan pemerintahan desa pertama kali dimuat dalam Undang-Undang Nomor 1 Tahun 1965 tentang Desa praja disebut dengan keputusan desa praja. ${ }^{6}$ Pada masa Orde Baru, peraturan desa tidak dikenal karena tingkat desa hanya dikenal Keputusan Desa sebagaimana diatur dalam Pasal 18 Undang-Undang Nomor 5 Tahun 1979. Keputusan Desa kemudian melalui Undang-Undang Nomor 22 Tahun 1999 tentang Pemerintahan Daerah, berubah nama menjadi Peraturan Desa. Peraturan desa ditetapkan berkaitan dengan konsekuensi penyelenggaraan kewenangan untuk mengurus rumah tangganya sendiri, atau dalam rangka melaksanakan kewenangan untuk mengatur dan mengurus kepentingan masyarakat desa setempat. ${ }^{7}$ Artinya, undangundang tersebut menunjukkan bahwa, produk hukum peraturan desa diakui keberadaannya sebagai suatu perangkat dasar legitimasi penyelenggaraan pemerintahan desa, dengan kata lain peraturan desa disusun sebagai acuan dalam melaksanakan pemerintahan dan pembangunan di Desa. Pemerintahan desa memiliki kemandirian dalam menjalankan roda pemerintahan di desa dibanding pada saat orde lama dan orde baru karena telah diberi kewenangan untuk membentuk suatu peraturan desa. UndangUndang Nomor 32 Tahun 2004 tentang Pemerintahan Daerah, menyatakan BPD memiliki peranan yang semakin kuat bersama Kepala Desa sebagai penyelenggaraan pemerintahan desa karena memiliki fungsi menetapkan peraturan desa bersama kepala desa, menampung dan menyalurkan aspirasi masyarakat, anggaran pendapatan dan belanja desa, dan keputusan kepala desa. ${ }^{8}$

Selain itu, menurut Pasal 209 Undang-Undang Nomor 32 Tahun 2004 tentang Pemerintahan Daerah, Badan Permusyawaratan Desa berfungsi menetapkan Peraturan Desa bersama Kepala Desa, menampung dan menyalurkan aspirasi masyarakat. Selanjutnya, Pasal 212 ayat (5) Undang-Undang Nomor 32 Tahun 2004 tentang

6 Yando Zakaria dan Abih Tandeh, Masyarakat Desa di Bawah Rezim Orde Baru, Jakarta Lembaga Studi dan Advokasi Masyarakat, 2000, hlm. 25.

7 Ryan Aprilianto, Aminuddin Kasim, Leli Tibaka, Kedudukan Peraturan Desa Dalam Penyelenggaraan Pemerintahan Desa, Jurnal Legal Opinion, Volume 6, No. 3, 2018, hlm. 251-252.

8 Hanif Nurcholis, Pertumbuhan dan Penyelenggaraan Pemerintahan Desa, Jakarta: Penerbit Erlangga, 2011, hlm. 65-66. 
Pemerintahan Daerah menyatakan bahwa pengelolaan keuangan desa sebagaimana dimaksud pada ayat (2) dilakukan oleh Kepala Desa yang dituangkan dalam Peraturan Desa tentang anggaran pendapatan dan belanja desa. Memang dalam Undang-Undang Nomor 32 Tahun 2004 hanya Pasal 212 ayat (5) yang secara tegas menyebutkan materi muatan Peraturan Desa yaitu yang menyangkut pengelolaan keuangan desa.

Muatan Perdes adalah seluruh materi muatan dalam rangka penyelenggaraan otonomi desa dan menampung kondisi khusus desa. Rancangan Perdes dapat berasal BPD dan Kepala Desa. Program penyusunan Perdes dilakukan dalam suatu program legislasi desa, sehingga diharapkan tidak terjadi tumpang tindih dalam penyiapan suatu materi Perdes. Ada beberapa jenis Perdes yang ditetapkan oleh Pemerintahan Desa antara lain: (1) Retribusi Desa, (2) Tata Kelola Kawasan Hutan Rakyat, (3) Rencana Konservasi Desa, (4) Tata Ruang Wilayah Desa, (5) Anggaran Pendapatan dan Belanja Desa (APBDes), (6) Perangkat Desa, (7) Badan Usaha Milik Desa (BUMDes), dan peraturan umum lainnya. Pembentukan Perdes yang baik harus berdasarkan pada asas pembentukan peraturan perundang-undangan sebagai berikut : (a) kejelasan tujuan, (b) kelembagaan atau organ pembentuk yang tepat, (c) kesesuaian antara jenis dan materi muatan, (d) dapat dilaksanakan, (e) kedayagunaan dan kehasilgunaan, (f) kejelasan rumusan, dan (g) keterbukaan. Selanjutnya, penyusunan Perdes harus memenuhi tiga aspek, yakni yuridis, filosofis, dan sosiologis. Sering kali penyusunan perda mengabaikan aspek sosiologis, yakni hukum yang berlaku di masyarakat, dan karena tidak melihat potensi dan karakteristik masyarakat, implementasi Perda maupun Perdes banyak terganggu, bertentangan dengan aturan yang lebih tinggi, serta tumpang tindih antara kebijakan pusat dan daerah.

\section{Kedudukan Hukum Peraturan Desa}

Terbentuk Undang-Undang Nomor 12 Tahun 2011 tentang Pembentukan Peraturan Perundang-undangan, yang mencabut Undang-Undang Nomor 10 Tahun 2004. Dalam Undang-Undang Nomor 12 Tahun 2011 ini menyatakan dalam Bab III mengenai jenis, hierarki dan materi muatan peraturan perundang-undangan. Pasal 7 ayat (1) UndangUndang Nomor 12 Tahun 2011 menegaskan jenis dan hierarki peraturan perundangundang yang berlaku di Indonesia sebagai suatu peraturan perundang-undangan. ${ }^{9}$

9 Ryan Aprilianto, Aminuddin Kasim, Leli Tibaka, Op.cit., hlm. 255. 
Undang-Undang Nomor 12 Tahun 2011 tentang Pembentukan Peraturan Perundang-undangan, Peraturan Desa tidak disebutkan secara eksplisit sebagai salah satu jenis peraturan perundang-undangan. Hal ini dikarenakan akan bertentangan dengan apa yang dimaksud Pasal 24A ayat (1) UUD NRI Tahun 1945, dimana ketika peraturan desa dikategorikan peraturan perundang-undangan di bawah undang-undang dapat dijadikan objek pengujian Mahkamah Agung. Hal tersebut dianggap tidak realistis karena akan membebani Mahkamah Agung dengan tugas-tugas yang sangat banyak. Akan tetapi, kedudukan peraturan desa sebenarnya masih termasuk peraturan perundang-undangan. Hal ini didasarkan pada ketentuan Pasal 8 ayat (1) Undang- Undang Nomor 12 Tahun 2011 yang menyatakan bahwa: "Jenis Peraturan Perundang-undangan selain sebagaimana dimaksud dalam pasal 7 ayat (1) mencakup peraturan yang ditetapkan oleh Majelis Permusyawaratan Rakyat, Dewan Perwakilan Rakyat, Dewan Perwakilan Daerah, Mahkamah Agung, Mahkamah Konstitusi, Badan Pemeriksa Keuangan, Komisi Yudisial, Bank Indonesia, Menteri, badan lembaga atau komisi yang setingkat yang dibentuk Undang-undang atau Pemerintah atas perintah Undang-Undang, Dewan Perwakilan Rakyat Daerah Provinsi, Gubernur, Dewan Perwakilan Rakyat Daerah Kabupaten/Kota, Bupati/Walikota, Kepala Desa atau yang setingkat". ${ }^{10}$

Undang-Undang Nomor 12 Tahun 2011 menganut asas kesesuaian antara jenis, hierarki, dan materi muatan. Asas ini mengandung arti bahwa dalam pembentukan peraturan perundang-undangan harus benar-benar memperhatikan materi muatan yang tepat sesuai dengan jenis dan hierarki peraturan perundang-undangan. Pasal 8 ayat (2) Undang-undang Nomor 12 Tahun 2011 tentang Pembentukan Peraturan Perundangundangan yang menyatakan bahwa: "Peraturan Perundang-undangan sebagaimana dimaksud pada ayat (1) diakui keberadaannya dan mempunyai kekuatan hukum mengikat sepanjang diperintahkan oleh Peraturan Perundang-undangan yang lebih tinggi atau dibentuk berdasarkan kewenangan".11

Gunarto Suhardi ${ }^{12}$ bahwa yang dimaksudkan kedudukan adalah keberadaan, posisinya dan kemandiriannya lembaga tersebut dihadapkan dengan lembaga lainnya. Hal ini dikuatkan dengan pendapat Soebagio dan Slamet Supriatna yang mengatakan bahwa

10 Ibid., hlm. 255.

11 Ibid., hlm. 256.

12 Sadjijono, Seri Hukum Kepolisian, Polri dan Good Governance, Surabaya: Laksbang Mediatama, 2008, hlm. 67 dikutip dari Gunarto Suhardi, Kedudukan dan Wewenang Lembaga Pengurusan Piutang Negara Dalam Perspektif Hukum Administrasi, Ringkasan Disertasi yang dipertahankan pada Tahun 2000, hlm. 6. 
berbicara mengenai kedudukan tidak lain membicarakan keberadaan. Jadi, masalah kedudukan peraturan desa tidak lain adalah masalah keberadaan peraturan desa dalam sistem perundang-undangan dan struktur pemerintahan (organisasi kenegaraan). ${ }^{13}$

Bila melihat ketentuan Pasal 1 angka 2 UU 12/2011 tentang definisi peraturan perundang-undangan disebutkan "Peraturan Perundang-undangan adalah peraturan tertulis yang memuat norma hukum yang mengikat secara umum dan dibentuk atau ditetapkan oleh lembaga negara atau pejabat yang berwenang melalui prosedur yang ditetapkan dalam Peraturan Perundang-undangan." Menurut Maria Farida ${ }^{14}$ menetapkan peraturan desa sebagai peraturan perundang-undangan adalah tidak tepat, dan tidak sesuai dengan ketentuan dalam UU 32/2004. Dengan pendapat tersebut bukan berarti bahwa badan perwakilan desa atau nama lainnya bersama kepala desa tidak boleh atau tidak dapat membentuk suatu Peraturan Desa atau nama lainnya, badan perwakilan desa atau nama lainnya bersama kepala desa tetap dapat membentuk suatu peraturan desa, yang bersifat mengatur (dan mengikat secara umum), dalam arti peraturan di bidang penyelenggaraan pemerintahan saja, tetapi tidak sebagai peraturan perundang-undangan. Jadi bila dikaitkan antara ketentuan Pasal 1 angka 2 UU 12/2011, Pasal 206 UU 32/2004 jo. Pasal 7 dan 8 PP 72/2005 beserta penjelasannya dengan konsep penyelenggaraan pemerintahan di atas, maka peraturan desa berfungsi dalam rangka untuk melaksanakan kewenangan pemerintahan yang berasal dari peraturan perundangundangan, wewenang yang berasal dari kabupaten/kota yang diserahkan kepada desa, wewenang dalam rangka tugas pembantuan yang berasal dari pemerintah pusat, pemerintah provinsi, atau pemerintah kabupaten/kota, atau wewenang yang berasal dari hak asal-usul desa. Namun, peraturan desa bukanlah peraturan perundang-undangan seperti yang dimaksud Pasal 1 angka 2 UU 12/2011, peraturan desa hanya sebagai instrumen penyelenggaraan pemerintahan di desa.

Eksistensi peraturan desa dalam perkembangannya tidak untuk melaksanakan otonomi, namun hanya sebagai instrumen untuk melaksanakan fungsi pemerintahan di desa. Fungsi pemerintahan tersebut berasal dari tugas-tugas pembantuan yang berasal dari tingkat pemerintahan yang lebih tinggi yaitu kabupaten/kota, sedangkan kedudukan peraturan desa menurut UU 12/2011 adalah di bawah peraturan yang lebih tinggi sesuai

13 Sadjijono, Seri Hukum Kepolisian, Polri dan Good Governance, Surabaya: Laksbang Mediatama, 2008, hlm. 68.

14 Maria Farida, Ilmu Perundang-Undangan I (Jenis, Fungsi, Materi Muatan), Yogyakarta: Kanisius, 2007, hlm. 102. 
hierarki Pasal 7 ayat (1) UU 12/2011, atau peraturan desa dapat dibentuk sepanjang diperintahkan oleh peraturan perundang-undangan yang lebih tinggi atau bisa juga dibentuk berdasarkan kewenangan. ${ }^{15}$

Dibentuk berdasarkan kewenangan memiliki makna bahwa peraturan desa dapat dibentuk melalui delegasi atau mandat dari pemerintahan yang lebih tinggi dengan kata lain urusan pemerintahan yang menjadi kewenangan kabupaten/kota yang diserahkan pengaturannya kepada desa atau tugas pembantuan dari Pemerintah, pemerintah provinsi, dan/atau pemerintah kabupaten/kota, selain itu dalam pembentukannya, peraturan desa dilarang bertentangan dengan peraturan yang lebih tinggi dan/atau kepentingan umum. Peraturan desa juga berfungsi dalam rangka untuk melaksanakan kewenangan pemerintahan yang berasal dari peraturan perundang-undangan, wewenang yang berasal dari kabupaten/kota yang diserahkan kepada desa, wewenang dalam rangka tugas pembantuan yang berasal dari pemerintah pusat, pemerintah provinsi, atau pemerintah kabupaten/kota, atau wewenang yang berasal dari hak asal-usul desa. Namun, peraturan desa bukanlah peraturan perundang-undangan seperti yang dimaksud Pasal 1 angka 2 UU 12/2011, peraturan desa hanya sebagai instrumen penyelenggaraan pemerintahan di desa. ${ }^{16}$

Jadi Peraturan Desa berdasarkan Undang-Undang No. 12 Tahun 2011 dipisahkan eksistensinya sebagai Peraturan Daerah sebagaimana diatur oleh Undang-Undang No. 10 Tahun 2004. Dengan kata lain posisi peraturan desa sekarang ini menunjukkan bukan merupakan peraturan daerah lagi.

\section{Sistem Pengujian Peraturan Desa Dalam Sistem Hukum Perundang-undangan Model Pengujian Peraturan Desa}

Konsep judicial review berasal dari negara-negara yang menganut supremasi konstitusi. Istilah judicial review itu sendiri merupakan istilah khas hukum tata negara Amerika Serikat yang artinya wewenang lembaga pengadilan untuk membatalkan setiap tindakan pemerintah yang bertentangan dengan konstitusi. Judicial review merupakan mekanisme pengujian peraturan perundang-undangan tertentu oleh hakim. Pengujian itu dilakukan

\footnotetext{
15 Bagus Oktafian Abrianto, Eksistensi Peraturan Desa Dalam Sistem Ketatanegaraan dan PerundangUndangan Di Indonesia, Yuridika-Volume. 26-No. 3, September-Desember 2011, Surabaya, hlm. 245.

16 Ibid., hlm. 245.
} 
atas suatu ketentuan peraturan perundang-undangan terhadap peraturan perundangundangan yang lebih tinggi atau terhadap konstitusi sebagai hukum tertinggi. ${ }^{17}$

Mengenai hak menguji dalam praktiknya dikenal dua macam hak menguji (toetsingsrecht), yaitu: a. Hak menguji formal (formele toetsingsrecht); dan b. Hak menguji material (materiele toetsingsrecht). Hak menguji formal adalah wewenang untuk menilai sesuatu produk legislatif seperti undang-undang. Pengujian formal biasanya terkait dengan soal-soal prosedural dan berkenaan dengan legalitas kompetensi institusi yang membuatnya. ${ }^{18}$ Pengujian material berkaitan dengan kemungkinan pertentangan isi muatan suatu peraturan dengan peraturan lain yang lebih tinggi ataupun menyangkut kekhususan-kekhususan yang dimiliki suatu peraturan dibandingkan dengan normanorma yang berlaku umum. ${ }^{19}$

Pengujian peraturan perundang-undangan jika dipandang berdasarkan waktu pengujian, dibagi menjadi dua istilah yaitu review dan preview. Review berarti memandang, menilai, atau menguji kembali. Sedangkan preview adalah kegiatan memandangi sesuatu lebih dulu dari sempurnanya keadaan objek yang dipandang itu. Jika peraturan perundang-undangan itu sudah sah sebagai peraturan perundang-undangan, maka pengujian dapat disebut sebagai review. Akan tetapi, jika statusnya masih sebagai rancangan peraturan perundang-undangan dan belum diundangkan secara resmi sebagai peraturan perundang-undangan, maka pengujiannya tidak dapat disebut sebagai review, melainkan preview.

Jadi, pengujian terhadap peraturan desa dilakukan dengan mekanisme pengujian secara executive preview dan executive review. Mekanisme executive preview dan executive review merupakan kewenangan Bupati/Walikota yang lahir dari proses pengawasan secara preventif ataupun refresif terhadap produk hukum di desa.

\section{Kewenangan Pengujian Peraturan Desa}

Penyelenggaraan urusan pemerintahan desa, yang disebut dengan urusan pemerintahan desa adalah urusan yang menjadi tanggung jawab atau tugas pemerintah desa. Agar urusan pemerintahan yang menjadi kewenangan desa tersebut dapat terlaksana dengan

\footnotetext{
17 Achmad Mulyanto, Problematika Pengujian Peraturan Perundang-Undangan (Judicial Review) Pada Mahkamah Agung Dan Mahkamah Konstitusi, Jurnal Yustisial Edisi 85 Januari-April 2013, hlm. 56.

18 Fatmawati, Hak Menguji (Toetsingsrecht) Yang Dimiliki Hakim Dalam Sistem Hukum Indonesia, Jakarta: RajaGrafindo Persada, 2005, hlm. 5.

19 Ibid., hlm. 6
} 
baik, maka dibentuklah suatu Peraturan Desa (selanjutnya disebut Perdes). Pada prinsipnya, Perdes berfungsi : Pertama, untuk melindungi secara normatif adat istiadat yang secara turun temurun diakui oleh masyarakat desa setempat. Kedua, sebagai sarana untuk menormakan kewenangan-kewenangan yang menjadi urusan desa, seperti hak asal usul desa, kewenangan kabupaten kota yang diserahkan pengaturannya kepada desa, tugas pembantuan, dan kewenangan lain berdasarkan perintah Peraturan Perundangundangan di atasnya. Ketiga, sebagai sarana normatif untuk menampung dan menyalurkan aspirasi masyarakat desa. ${ }^{20}$

Perdes di dalam Pasal 1 angka 7 Undang-undang Nomor 6 Tahun 2014 Tentang Desa adalah peraturan perundang-undangan yang ditetapkan oleh Kepala Desa setelah dibahas dan disepakati bersama Badan Permusyawaratan Desa. Sedangkan, Peraturan Desa berdasarkan Undang-undang sebelumnya yakni Undang-Undang Nomor 10 Tahun 2004, keberadaannya diatur dalam Pasal 7 ayat (1) yang menentukan bahwa Peraturan Desa termasuk salah satu dari peraturan perundang-undangan, ${ }^{21}$ ditegaskan lagi dalam Pasal 7 ayat (2) bahwa Peraturan Daerah salah satunya adalah berupa Peraturan Desa. Hal ini menunjukkan bahwa desa yang seharusnya memiliki pola peraturan yang tersendiri menjadi sama dengan peraturan yang lainnya. Pencabutan Undang-Undang Nomor 10 Tahun 2004 Tentang Pembentukan Peraturan Perundang-undangan, yang kemudian digantikan dengan Undang-Undang Nomor 12 Tahun 2011 Tentang Pembentukan Peraturan Perundang-undangan, memberikan penafsiran berbeda mengenai letak atau kedudukan Perades. Hal ini disebabkan karena Peraturan Desa tidak dicantumkan sebagai salah satu hierarki Peraturan Perundang-undangan. ${ }^{22}$

Maka, kewenangan untuk melakukan pengujian peraturan perundang-undangan bertujuan untuk menjaga dan memastikan pelaksanaan penyelenggaraan pemerintahan yang dilaksanakan berdasar pada peraturan perundang-undangan sebagai dasar untuk melaksanakan aktivitas pemerintahan agar selalu selaras dan sejalan dengan UUD NKRI 1945. Oleh karena itu, proses pengujian peraturan desa menjadi suatu hal yang sangat penting dilakukan, untuk mengharmoniskan dengan ketentuan peraturan perundang-

20 I Gede Pantja Astawa \& Suprin Na'a, Dinamika Hukum Dan Ilmu Perundangan-undangan Di Indonesia, Cet. 1, Ed. 1, Bandung: Alumni, 2008, hlm. 72

21 Undang-Undang Tentang Pembentukan Peraturan Perundang-undangan, Nomor 10 Tahun 2004, Pasal 7 ayat (1).

22 Undang-Undang Tentang Pembentukan Peraturan Perundang-undangan, Nomor 12 Tahun 2011, Pasal 7 ayat (1). 
undangan yang lebih tinggi dan kepentingan umum selain itu pengujian terhadap peraturan desa untuk melindungi masyarakat dari kesewenang-wenangan penguasa dan untuk melindungi hak dari masyarakat desa. Guna menjamin dan memastikan pembentukan peraturan desa tidak bertentangan dengan peraturan perundang-undangan dan kepentingan umum maka sangat diperlukan pengujian terhadap peraturan desa.

Secara langsung berarti pembentukan Peraturan Desa haruslah sesuai dengan kaidah dan aturan yang telah diatur dalam Undang-Undang Nomor 12 Tahun 2011 dan tidak boleh bertentangan dengan aturan yang lebih tinggi, namun di sisi lain menurut Undang-Undang Nomor 23 Tahun 2014, desa adalah sub-ordinasi dari kabupaten dan Peraturan Desa merupakan aturan pelaksana dari Peraturan Daerah Kabupaten/Kota, sehingga harus mendapat pengawasan oleh Pemerintah Daerah Kabupaten/Kota agar tidak bertentangan dengan peraturan yang lebih tinggi. Artinya, Peraturan Desa sebagai salah satu produk peraturan perundang-undangan yang pembentukan harus berdasarkan Peraturan Daerah Kabupaten/Kota apabila materi muatan di dalamnya bertentangan dengan peraturan perundang-undangan yang lebih tinggi (Undang-Undang sampai dengan Peraturan Daerah Kabupaten/Kota) dapat dibatalkan oleh Kepala Daerah Kabupaten/Kota apabila materi muatannya dinilai bertentangan dengan peraturan perundang-undangan yang lebih tinggi. ${ }^{23}$

\section{KESIMPULAN}

Berdasarkan uraian-uraian yang telah dijelaskan maka penulis dapat menyimpulkan bahwa:

1. Setelah berlakunya Undang-Undang Nomor 12 Tahun 2011, maka Peraturan Desa tidak lagi disebutkan secara eksplisit sebagai salah satu jenis peraturan perundang-undangan. Artinya, kedudukan peraturan desa dianggap hanya sebagai penjabaran lebih lanjut dari peraturan perundang-undangan yang lebih tinggi.

2. Peraturan Desa yang berbentuk rancangan Peraturan Desa, harus mendapatkan evaluasi dan pengawasan dari Bupati/Walikota. Terkait dengan hal pengujian terhadap peraturan desa dilakukan dengan mekanisme pengujian secara

23 Lanang Sakti, Kewenangan Pengawasan Dan Pengujian Terhadap Peraturan Desa Dari Perspektif Peraturan Perundang-Undangan, Jurnal IUS-Vol. IV, Nomor. 2, Agustus 2016, hlm. 167. 
executive preview dan ataupun executive review yang merupakan kewenangan Bupati/Walikota terhadap produk hukum di desa.

\section{Daftar Pustaka}

\section{Buku}

Astawa, I Gede Pantja \& Suprin Na'a, Dinamika Hukum Dan Ilmu Perundangan-undangan Di Indonesia, Cet. 1, Ed. 1, Bandung: Alumni, 2008.

Farida, Maria, Ilmu Perundang-Undangan I (Jenis, Fungsi, Materi Muatan), Yogyakarta: Kanisius, 2007.

Fatmawati, Hak Menguji (Toetsingsrecht) Yang Dimiliki Hakim Dalam Sistem Hukum Indonesia, Jakarta: RajaGrafindo Persada, 2005.

Marzuki, Peter Mahmud, Penelitian Hukum, Jakarta: Kencana Prenada Media Group, 2005.

Nurcholis, Hanif, Pertumbuhan dan Penyelenggaraan Pemerintahan Desa, Jakarta: Penerbit Erlangga, 2011.

Rahardjo, Pengantar Sosiologi Pedesaan dan Pertanian, Yogyakarta: Gadjah Mada University Press, 1999.

Sadjijono, Seri Hukum Kepolisian, Polri dan Good Governance, Surabaya: Laksbang Mediatama, 2008.

Soemitro, Ronny Hanitijo, Metode Penelitian Hukum dan Jurimetri, Jakarta: Ghalia Indonesia, 1990.

Suhardi, Gunarto, Kedudukan dan Wewenang Lembaga Pengurusan Piutang Negara Dalam Perspektif Hukum Administrasi, Ringkasan Disertasi yang dipertahankan pada Tahun 2000.

Zakaria, Yando dan Abih Tandeh, Masyarakat Desa di Bawah Rezim Orde Baru, Jakarta: Lembaga Studi dan Advokasi Masyarakat, 2000.

\section{Jurnal}

Abrianto, Bagus Oktafian, Eksistensi Peraturan Desa Dalam Sistem Ketatanegaraan dan Perundang-Undangan Di Indonesia, Yuridika-Volume. 26-No. 3, SeptemberDesember 2011, Surabaya.

Aprilianto, Ryan, Aminuddin Kasim, Leli Tibaka, Kedudukan Peraturan Desa Dalam Penyelenggaraan Pemerintahan Desa, Jurnal Legal Opinion, Volume 6, No. 3, 2018. 
Aziz, Machmud, Pengujian Peraturan Perundang-Undangan dalam Sistem Peraturan Perundang-Undangan Indonesia, Jurnal Konstitusi, Volume 7, Nomor 5, Oktober 2010.

Mulyanto, Achmad, Problematika Pengujian Peraturan Perundang-Undangan (Judicial Review) Pada Mahkamah Agung Dan Mahkamah Konstitusi, Jurnal Yustisial Edisi 85 Januari-April 2013.

Sakti, Lanang, Kewenangan Pengawasan Dan Pengujian Terhadap Peraturan Desa Dari Perspektif Peraturan Perundang-Undangan, Jurnal IUS-Vol. IV, Nomor. 2, Agustus 2016.

\section{Perundang-Undangan}

Undang-Undang Nomor 10 Tahun 2004 Tentang Pembentukan Peraturan Perundangundangan.

Undang-Undang Nomor 12 Tahun 2011 Tentang Pembentukan Peraturan Perundangundangan.

Undang-Undang Nomor 6 Tahun 2014 Tentang Desa. 